\title{
First report of QNRA isolated from extended spectrum B-lactamase producing hospital- acquired Klebsiella pheumoniae in Kuwait
}

\author{
L Vali*, AA Dashti, MM Jadaon, S El-Shazly, BT Jose \\ From International Conference on Prevention \& Infection Control (ICPIC 2011) \\ Geneva, Switzerland. 29 June - 2 July 2011
}

\section{Introduction / objectives}

Extended Spectrum beta-lactamase (ESBL)-mediated resistant Klebsiella pneumoniae are important opportunistic pathogens. In this study we investigated the prevalence of plasmid-mediated fluoroquinolone resistance in ESBLproducing $K$. pneumoniae in nosocomial infections in Kuwait.

\section{Methods}

From a total of 72 non-duplicate quinolone and cephalosporin resistant Enterobacteriacae obtained from October-December 2010 from Ahmadi hospital in Kuwait, 16 were K. pneumoniae. Antimicrobial susceptibility was determined by Vitek, Microscan, double disc diffusion, agar dilution and E-test against a panel of 26 antimicrobial agents. The presence of blaSHV, blaTEM, bla CTX-M, gyrA, parC, qnrA, qnrB, qnrS and class 1 integrons were determined by PCR and sequencing. Pulsed-field gel electrophoresis (PFGE) was used for typing the strains and the results were analysed according to Tenover criteria.

\section{Results}

All 16 isolates were resistant to all antibiotics tested including ciproflaxoacin (MIC $>4)$, tazobactam $(\mathrm{MIC}>16)$, cefotaxime $(\mathrm{MIC}>16)$ and ceftazidime $(\mathrm{MIC}>16)$; except for carbapenems, amikacin, and tigecycline. blaTEM, blaSHV\& \&blaCTX-M-15 were present in $81.25 \%$ (13), $81.25 \%$ (13) and $68.75 \%$ (11) respectively. Nine (56.25\%) isolates contained all three bla genes of which one harboured qnrA (A2 allele) and a class 1 integron. No mutations were found in gyrA and parC. PFGE revealed that

Kuwait University, Kuwait, Kuwait
K. pneumoniae isolates harbouring ESBL genes consisted of two distinct clones.

\section{Conclusion}

Contrary to a previous study, we hereby report the emergence of plasmid-mediated $q n r$ A gene among ESBL producing nosocomial K. pneumoniae for the first time in Kuwait. Identification of these strains are crucial for administering the correct antibiotic and preventing their spread among hospitalised patients.

\section{Disclosure of interest}

None declared.

Published: 29 June 2011

doi:10.1186/1753-6561-5-S6-P139

Cite this article as: Vali et al:: First report of QNRA isolated from extended spectrum B-lactamase producing hospital-acquired Klebsiella pheumoniae in Kuwait. BMC Proceedings 2011 5(Suppl 6):P139.

Submit your next manuscript to BioMed Central and take full advantage of:

- Convenient online submission

- Thorough peer review

- No space constraints or color figure charges

- Immediate publication on acceptance

- Inclusion in PubMed, CAS, Scopus and Google Scholar

- Research which is freely available for redistribution 